\title{
Adaptation of Mitochondrial Substrate Flux in a Mouse Model of Nonalcoholic Fatty Liver Disease
}

\author{
Pavla Staňková ${ }^{1}$, Otto Kučera ${ }^{1, * \mathbb{C}}$, Eva Peterová ${ }^{2}$, Halka Lotková $^{1}$, Tumisang Edward Maseko ${ }^{1}$, \\ Kateřina Nožičková ${ }^{1}$ and Zuzana Červinková ${ }^{1}$ (1) \\ 1 Department of Physiology, Faculty of Medicine in Hradec Králové, Charles University, Šimkova 870, \\ 50003 Hradec Králové, Czech Republic; stankovap@lfhk.cuni.cz (P.S.); lotko@lfhk.cuni.cz (H.L.); \\ MASEKOT@lfhk.cuni.cz (T.E.M.); katerina.nozickova@fnhk.cz (K.N.); wolff@lfhk.cuni.cz (Z.Č.) \\ 2 Department of Medical Biochemistry, Faculty of Medicine in Hradec Králové, Charles University, \\ Šimkova 870, 50003 Hradec Králové, Czech Republic; PeterovaE@lfhk.cuni.cz \\ * Correspondence: kucerao@lfhk.cuni.cz; Tel.: +420-495-816-186
}

Received: 15 January 2020; Accepted: 5 February 2020; Published: 7 February 2020

\begin{abstract}
Maladaptation of mitochondrial oxidative flux seems to be a considerable feature of nonalcoholic fatty liver disease (NAFLD). The aim of this work was to induce NAFLD in mice fed a Western-style diet (WD) and to evaluate liver mitochondrial functions. Experiments were performed on male C57BL/6J mice fed with a control diet or a WD for 24 weeks. Histological changes in liver and adipose tissue as well as hepatic expression of fibrotic and inflammatory genes and proteins were evaluated. The mitochondrial respiration was assessed by high-resolution respirometry. Oxidative stress was evaluated by measuring lipoperoxidation, glutathione, and reactive oxygen species level. Feeding mice a WD induced adipose tissue inflammation and massive liver steatosis accompanied by mild inflammation and fibrosis. We found decreased succinate-activated mitochondrial respiration and decreased succinate dehydrogenase (SDH) activity in the mice fed a WD. The oxidative flux with other substrates was not affected. We observed increased ketogenic capacity, but no impact on the capacity for fatty acid oxidation. We did not confirm the presence of oxidative stress. Mitochondria in this stage of the disease are adapted to increased substrate flux. However, inhibition of SDH can lead to the accumulation of succinate, an important signaling molecule associated with inflammation, fibrosis, and carcinogenesis.
\end{abstract}

Keywords: nonalcoholic fatty liver disease; mitochondria; oxidative phosphorylation; respirometry

\section{Introduction}

The liver is a principal metabolic organ that governs body energy metabolism. Nonalcoholic fatty liver disease (NAFLD) is currently the most common chronic liver condition worldwide [1]. In the vast majority of cases, it is the consequence of chronic overnutrition, and NAFLD is now recognized as a hepatic manifestation of metabolic syndrome [2]. NAFLD encompasses a wide range of pathologies, including simple steatosis, nonalcoholic steatohepatitis (NASH), fibrosis, and ultimately cirrhosis, which may progress to hepatocellular carcinoma. The mechanism for the development and progression of NAFLD is multifactorial, and there are still substantial gaps in knowledge regarding NAFLD pathogenesis and treatment [3,4]. NAFLD is not simply a liver pathology; it is accompanied by whole-body metabolic changes.

At the systemic level, lipids are at the bottom of an oxidative hierarchy, and their utilization depends on the presence of other fuels [5]. The ability to freely switch between alternative fuels according to physiological and nutritional circumstances is called metabolic flexibility [6], and it relies on the action of insulin, glucagon, and other hormones. In the fed state, the insulin action removes 
competition for substrate utilization. When the storage capacity of the subcutaneous adipose tissue (AT) is exceeded, or impaired, insulin is not able to inhibit AT lipolysis, and fat begins to accumulate in other organs [7]. Insulin-resistant individuals continue to oxidize a mixture of fuels regardless of the nutritional context [6].

Oxidation of fatty acids (FAs) and other substrates occurs mainly in the mitochondria. Mitochondrial dysfunction and oxidative stress are detected in liver tissues from NAFLD patients [8]. However, studies of mitochondrial function in NAFLD are conflicting. The broad spectrum of conditions covered by the term NAFLD makes it difficult to compare studies directly, and alterations in mitochondrial energetics depend on the stage of the diseases, the susceptibility of the metabolic pathway, and the ability of hepatocytes to buffer and store excess lipids [9,10]. A better understanding of the mitochondrial pathways and their adaptive/maladaptive responses in NASH is essential. Without understanding the respiratory activities of mitochondria, it is impossible to understand other processes in mitochondria and cells [11].

Total caloric intake represents a key regulator of liver fat content [12]. It also appears that the contribution of nutrients and/or a combination of nutrients to the development and progression of NAFLD varies [12-14]. Fructose is metabolized preferentially in the liver and provides a source of energy that is not regulated by the energy status of the cell. High amounts of saturated fat, glucose, and/or fructose is a typical feature of the Western-style diet (WD) $[12,15,16]$. The development of obesity and NAFLD in humans occurs over years, and there are limitations to human tissue acquisition. Animal models that mimic human pathology are thus necessary. The WD-fed animal models most closely resemble the human condition $[2,3,17,18]$. The definition of a WD can differ based on composition and the percentage and types of fat, cholesterol, and sugar included [19]. The severity of diet-induced NAFLD also depends on the species, gender, animal strain, and substrain $[16,20]$. Reproducibility is of crucial importance in any animal model of disease. For this reason, we selected the WD mouse model of NASH using a standard commercially available diet and mice strain [18]. As changes in energy metabolism depend on the stage of the disease, a longitudinal dynamic analysis of NAFLD progression in this model was performed by the same research group [21].

The aim of this work was to reproduce a model of fibrosis-developing NASH in C57BL/6J mice fed a high-fat, high-fructose, and high-cholesterol WD [18,21]. We selected a feeding interval of 24 weeks, when noticeable liver inflammation and fibrosis were observed [21]. Because in vivo different available substrates simultaneously feed electrons to the electron transfer system (ETS), notably in the state of metabolic inflexibility, we evaluated liver mitochondrial functions using a mixture of respiratory substrates and substrate-uncoupler-inhibitor titration reference protocols [22].

\section{Results}

\subsection{Whole Body, Liver, and Epididymal Fat Weight}

Animals fed the WD gained significantly more weight $(p<0.01)$, and their absolute and relative liver weights and the amount of epididymal fat were higher in comparison with the mice fed the control diet (CD) $(p<0.01)$ (Table 1).

\subsection{Blood Analysis}

The activity of alanine transaminase (ALT) was higher in the mice fed the WD $(p<0.01)$, as were the cholesterol and bile acid concentrations $(p<0.01)$. The level of blood urea nitrogen (BUN) was lower in comparison with that of the control animals $(p<0.01)$. The activities of $\gamma$-glutamyl transferase (GGT) and alkaline phosphatase (ALP), as well as the concentrations of albumin and total bilirubin, were not significantly affected (Table 1$)$. 
Table 1. Phenotype and blood biochemistry.

\begin{tabular}{ccc}
\hline Parameter & CD & WD \\
\hline Body weight, $g$ & $30.5 \pm 3.27$ & $45.17 \pm 4.02^{* *}$ \\
Absolute liver weight, $\mathrm{g}$ & $1.42 \pm 0.18$ & $3.58 \pm 0.88^{* *}$ \\
Relative liver weight, $\%$ & $4.65 \pm 0.46$ & $7.83 \pm 1.38^{* *}$ \\
Epididymal fat weight, $\mathrm{g}$ & $0.80 \pm 0.25$ & $2.17 \pm 0.27^{* *}$ \\
ALT, $\mu \mathrm{kat} / \mathrm{L}$ & $0.45 \pm 0.08$ & $5.23 \pm 2.38^{* *}$ \\
ALP, $\mu \mathrm{kat} / \mathrm{L}$ & $0.62 \pm 0.42$ & $1.50 \pm 0.55$ \\
Cholesterol, $\mathrm{mmol} / \mathrm{L}$ & $2.52 \pm 0.45$ & $6.82 \pm 0.75^{* *}$ \\
Bile acids, $\mu \mathrm{mol} / \mathrm{L}$ & $<1$ & $10.00 \pm 3.16^{* *}$ \\
Total bilirubin, $\mu \mathrm{mol} / \mathrm{L}$ & $3.25 \pm 0.96$ & $3.75 \pm 0.50$ \\
BUN, mmol/L & $6.55 \pm 1.01$ & $4.58 \pm 0.83^{* *}$ \\
albumin, $\mathrm{g} / \mathrm{L}$ & $26.67 \pm 7.17$ & $28.00 \pm 2.92$ \\
GGT, $\mu \mathrm{kat} / \mathrm{L}$ & $<0.1$ & $<0.1$ \\
\hline
\end{tabular}

The results are expressed as the means $\pm \mathrm{SD} ;{ }^{* *} p<0.01$ ( $n=6$ each group). $\mathrm{CD}$, control diet; WD, Western-style diet.

\subsection{Epididymal Fat (eWAT)}

We observed characteristic macrophage crown-like structures surrounding dying or dead adipocytes in the eWAT of all mice reared on WD. Mice fed the CD showed no evidence of eWAT inflammation (Figure 1).
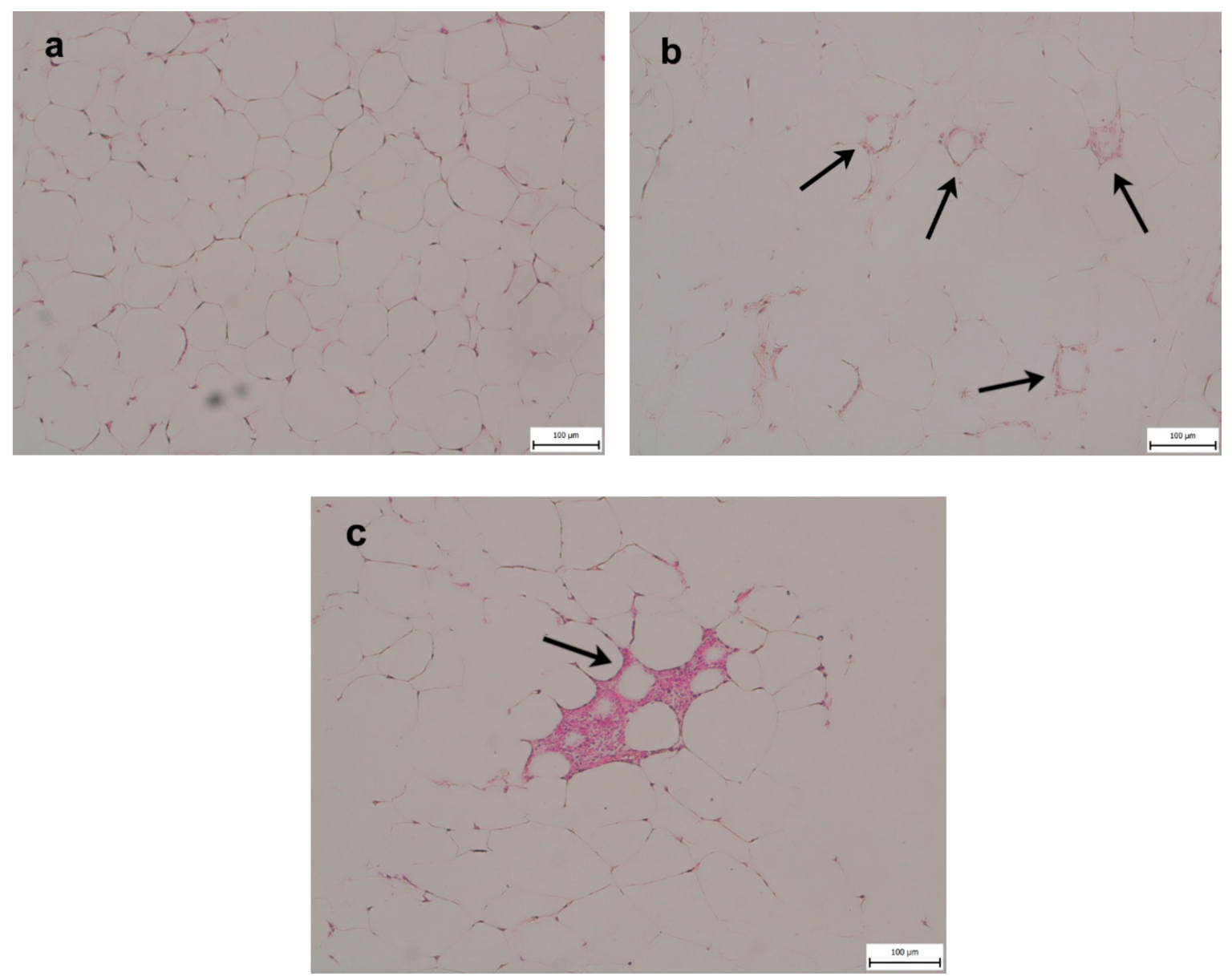

Figure 1. Epididymal fat histology (a) in mice fed a control diet (CD) and (b,c) Western-style diet (WD). Macrophage infiltration showing formation of crown-like structures (indicated by arrows) characteristic of stressed insulin-resistant dying adipocytes in the WD group. No indications of inflammation are seen in the CD group. 


\subsection{Steatosis, Inflammation, Fibrosis, and Apoptosis}

Histologically, the severity of the steatosis, inflammation, and fibrosis was evaluated using the NASH Clinical Research Network Scoring System [23]. All six animals in the WD group received a maximum score of 3 for steatosis. Steatosis was present in more than $98 \%$ of the hepatocytes and was found in both macrovesicular (60\%) and microvesicular (40\%) forms. Mild inflammation (score 1) was observed in three animals, and mild perisinusoidal fibrosis (score 1A) was observed in four animals from the WD group. There was no evidence of steatosis and fibrosis in the control group, and one mouse from this group received a score of 1 for inflammation. Hepatocellular ballooning was not observed (Figure 2). Steatosis in the WD group was confirmed by the increased level of the tissue triglycerides (TGs) and cholesterol (Figure 3), and mild inflammation by the level of liver tumor necrosis factor alpha (TNF- $\alpha$ ) and interleukin 6 (IL-6) (Figure 4). Although we observed a significant $(p<0.01)$ increase in hepatic gene expression of the regulators of fibrosis, transforming growth factor beta (TGF- $\beta$ ), and tissue inhibitor of metalloproteinases-1 (TIMP-1), in the WD group, we did not confirm their increased expression at the protein level (Figure $5 \mathrm{a}-\mathrm{d}$ ). The gene and protein expression levels of collagen type I alpha 2 chain (Col1A2) and alpha smooth muscle actin ( $\alpha$-SMA) were not significantly affected by the diet intake (Figure $5 \mathrm{e}-\mathrm{h}$ ). Gene expression of transcription factor p53 and cyclin-dependent kinase inhibitor 1 (p21) and the apoptotic proteins Bax and Bcl-2 were significantly higher in the WD group, but this increase was not confirmed at the protein level (Figure 6).
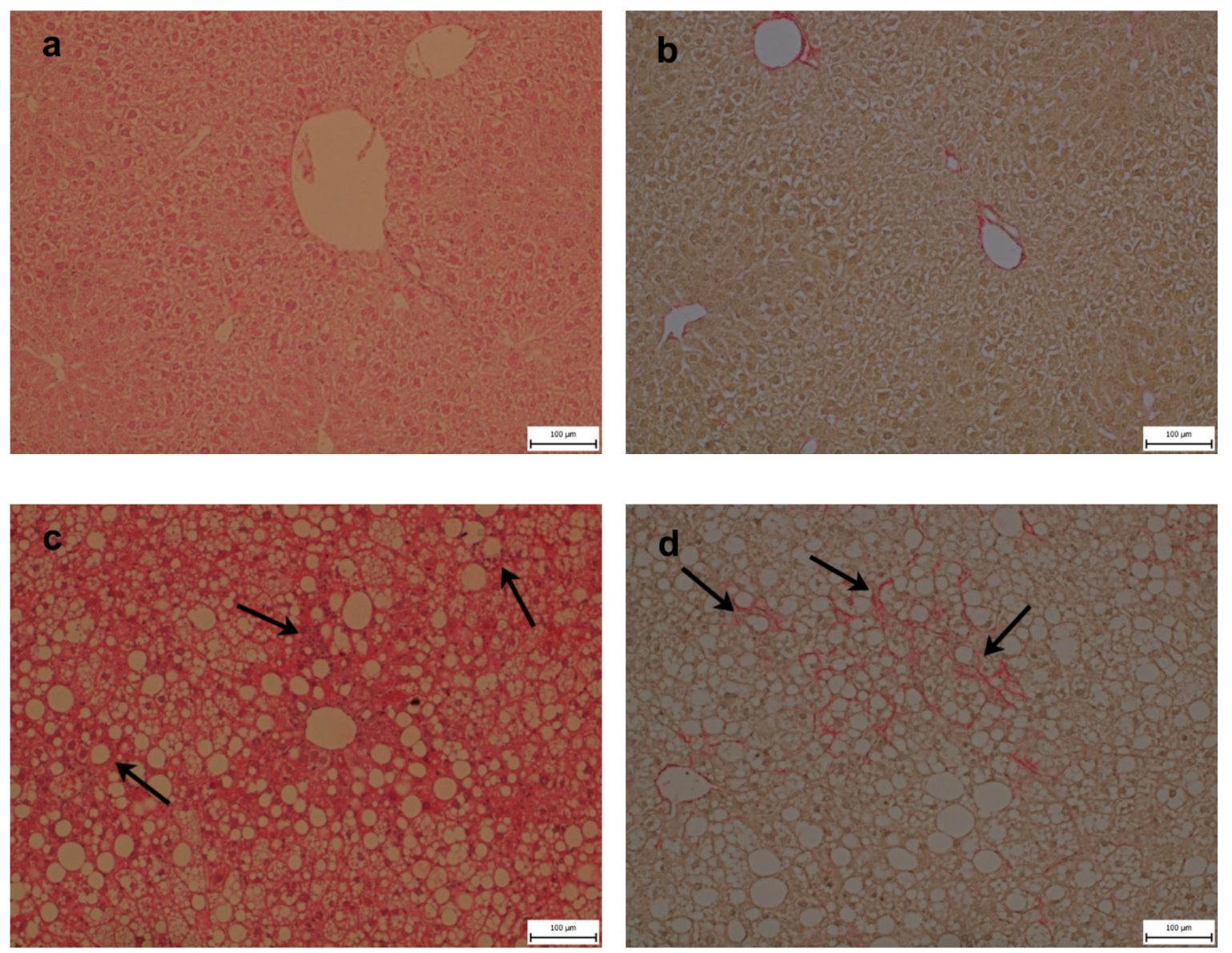

Figure 2. Liver histology $(\mathbf{a}, \mathbf{b})$ in mice fed a control diet (CD) and (c,d) Western-style diet (WD). $(\mathbf{a}, \mathbf{c})$ Hematoxylin and eosin sections of mice fed a WD reveal massive mixed steatosis with inflammatory infiltrated cells indicated by arrows. $(\mathbf{b}, \mathbf{d})$ Sirius red staining revealed mild perisinusoidal fibrosis indicated by arrows. 
a

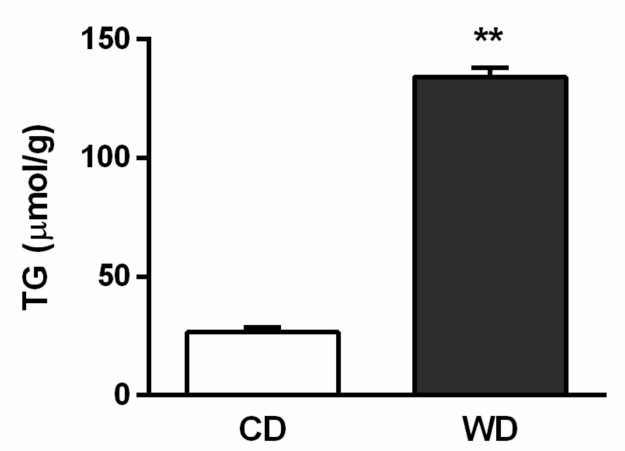

b

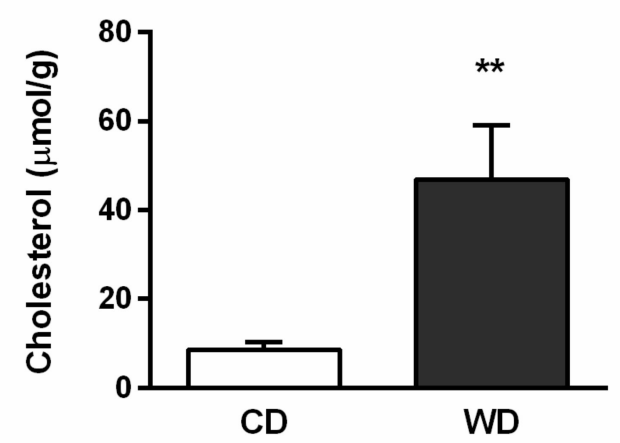

Figure 3. Hepatic lipids in mice fed a control diet (CD) and a Western-style diet (WD). (a) Total triglycerides (TGs) and (b) cholesterol content. The results are expressed as the means $\pm \mathrm{SD} ;{ }^{* *} p<0.01$ ( $n=6$ each group).

a

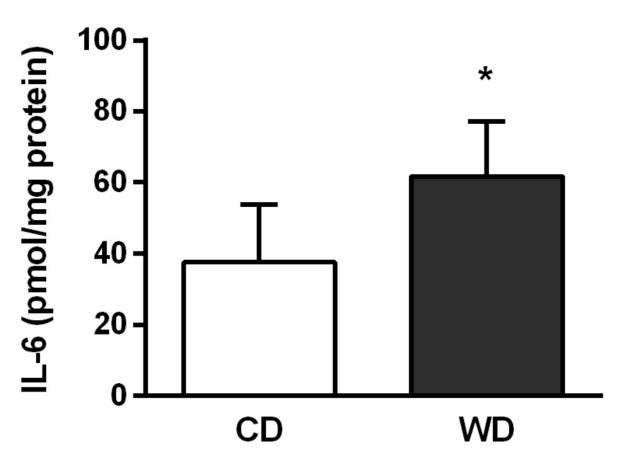

b

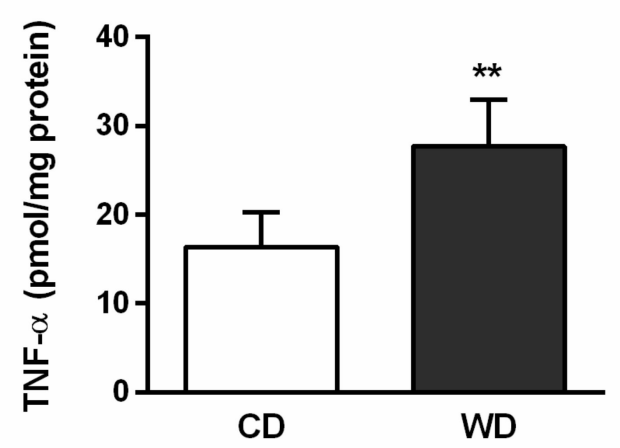

Figure 4. Hepatic inflammatory cytokines in mice fed a control diet (CD) and a Western-style diet (WD). (a) Levels of liver interleukin 6 (IL-6) and (b) tumor necrosis factor alpha (TNF- $\alpha$ ). The results are expressed as the means $\pm \mathrm{SD} ;{ }^{*} p<0.05,{ }^{* *} p<0.01$ ( $n=6$ each group).

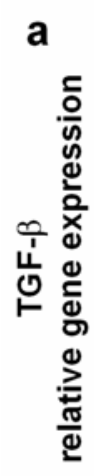

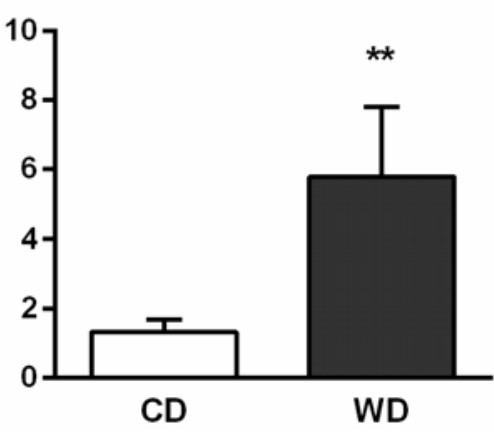

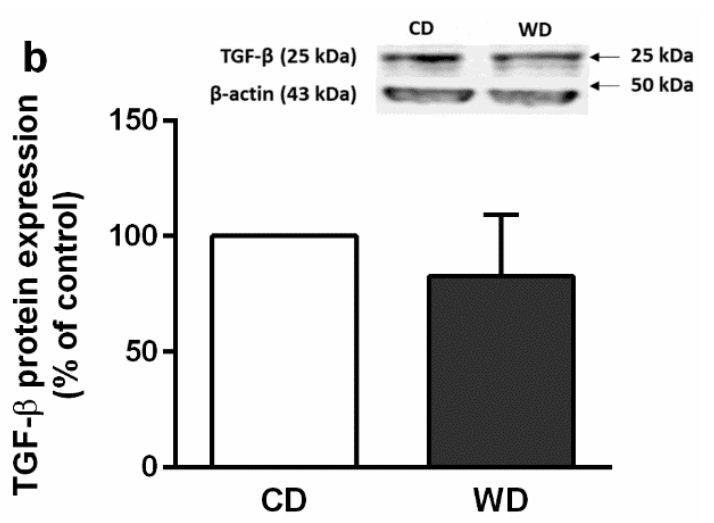

Figure 5. Cont. 
C

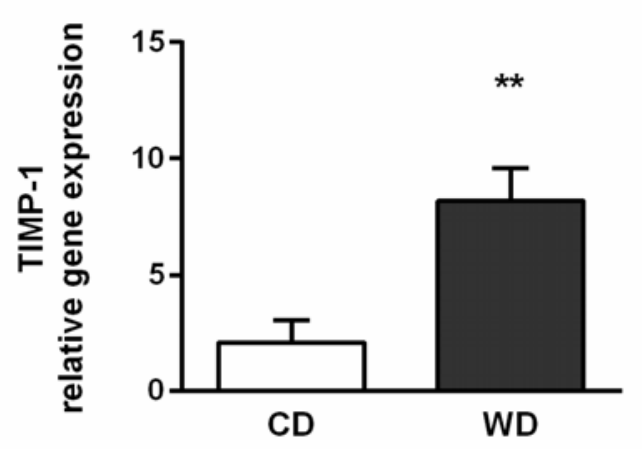

e

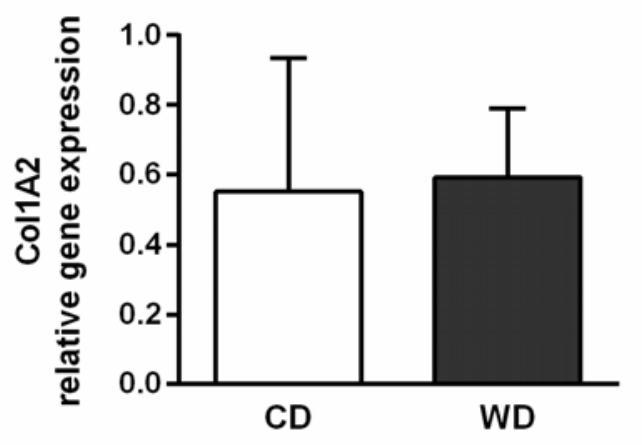

g

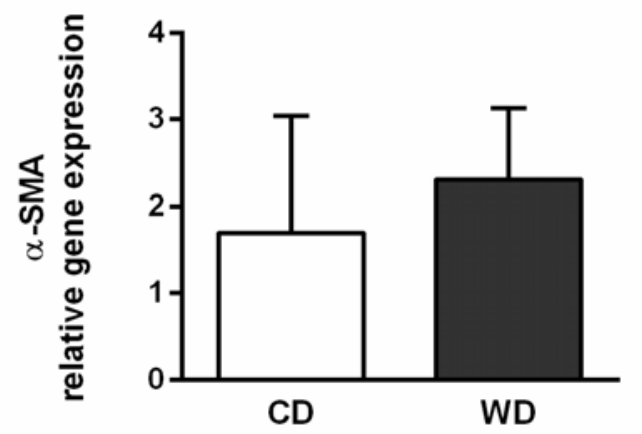

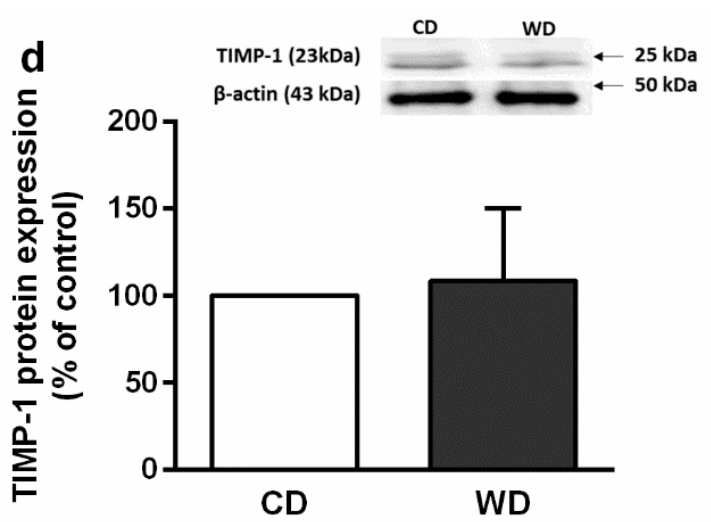
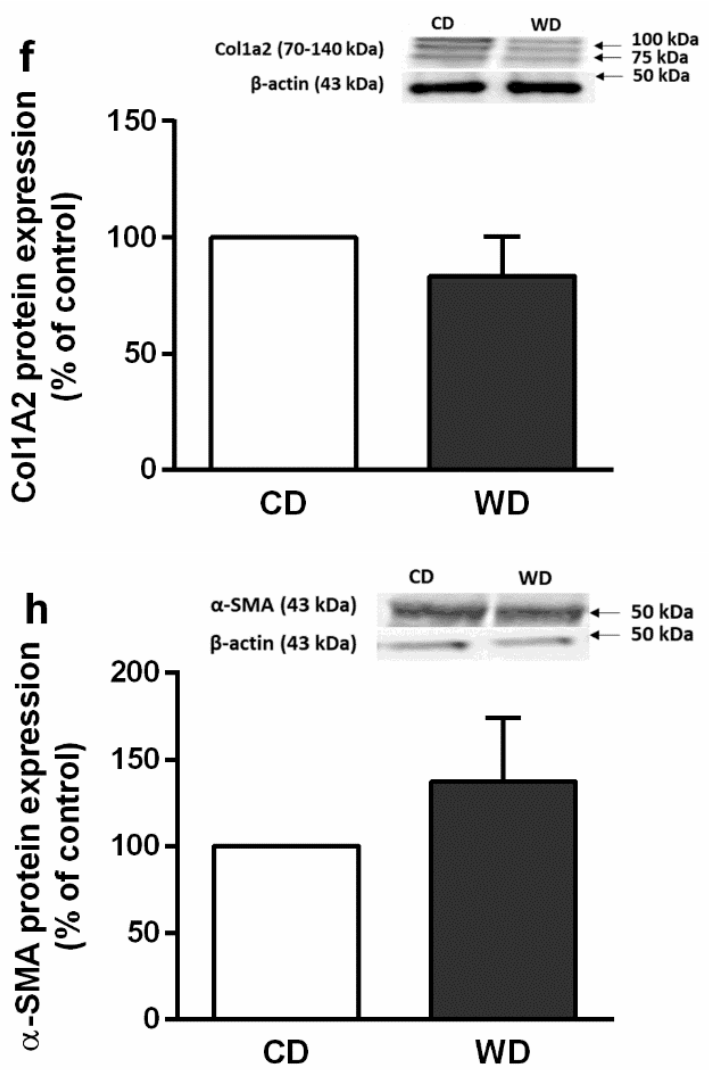

Figure 5. Markers of hepatic fibrosis and stellate cell activation in mice fed a control diet (CD) and a Western-style diet (WD). (a) Tumor growth factor beta (TGF- $\beta$ ) gene and (b) TGF- $\beta$ protein expression. (c) Tissue inhibitor of metalloproteinase-1 (TIMP-1) gene and (d) TIMP-1 protein expression. (e) Collagen type I alpha 2 chain (Col1A2) gene and (f) Col1A2 protein expression. (g) Alpha smooth muscle actin ( $\alpha$-SMA) gene and (h) $\alpha$-SMA protein expression. The results are expressed as the means $\pm \mathrm{SD} ;{ }^{* *} p<0.01$ ( $n=4-5$ each group). Representative Western blot images are shown in graphs. 
a

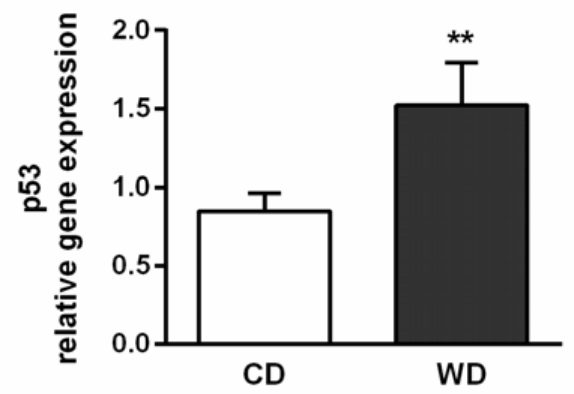

C
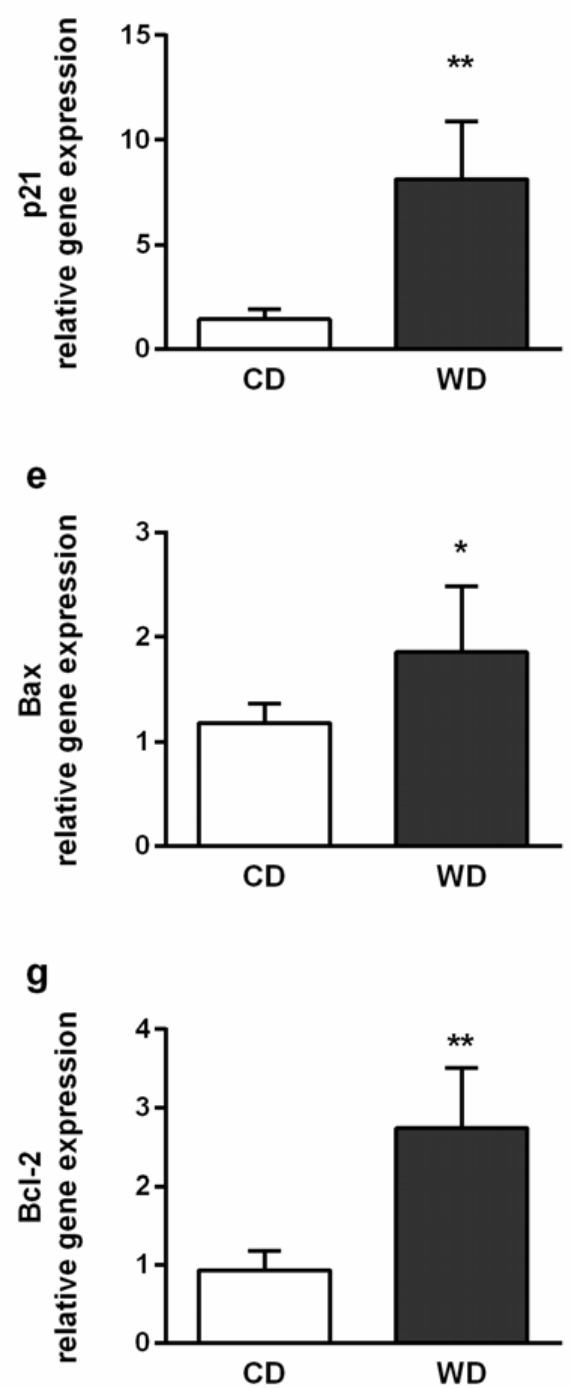
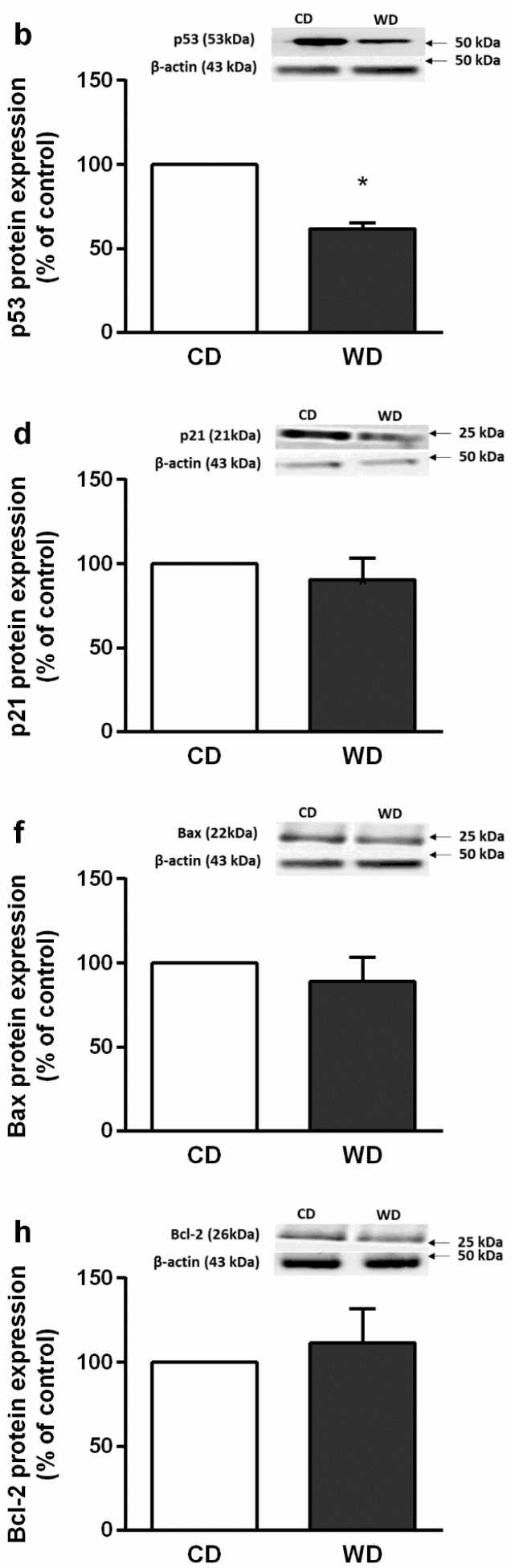

Figure 6. Markers of hepatic apoptosis in mice fed a control diet (CD) and a Western-style diet (WD). (a) Transcription factor p53 gene and (b) p53 protein expression. (c) Cyclin-dependent kinase inhibitor 1 (p21) gene and (d) p21 protein expression. (e) Proapoptotic protein Bax gene and (f) Bax protein expression. (g) Antiapoptotic protein Bcl-2 gene and (h) Bcl-2 protein expression. The results are expressed as the means $\pm \mathrm{SD} ;{ }^{*} p<0.05,{ }^{* *} p<0.01$ ( $n=4-5$ each group). Representative Western blot images are shown in graphs. 


\subsection{Oxidative Stress}

We did not confirm the presence of oxidative stress. Reduced glutathione (GSH) levels were equivalent in the liver homogenates from mice fed the $C D$ and WD diets (Figure $7 b$ ), and there was no significant difference in hepatic concentrations of thiobarbituric acid reactive substances (TBARS) (Figure 7a). To measure reactive oxygen species (ROS) production, the liver homogenates were incubated with a mixture of NADH-linked substrates, a mixture of $\mathrm{NADH}$ - and $\mathrm{FADH}_{2}$-linked substrates, and/or octanoylcarnitine in the presence (oxidative phosphorylation (OXPHOS) state) or absence of adenosine diphosphate (ADP) (leak state). At high redox potential (leak state), the production of ROS was significantly lower $(p<0.05)$ in the WD group with all the experimental substrate mixtures and also with $\mathrm{NADH}$ plus $\mathrm{FADH}_{2}$-linked substrates in the OXPHOS state in comparison with the CD group (Figure 7c). We found increased gene expression of uncoupling protein 2 (UCP-2) (Figure 8) in the mice fed the WD $(p<0.01)$.

a

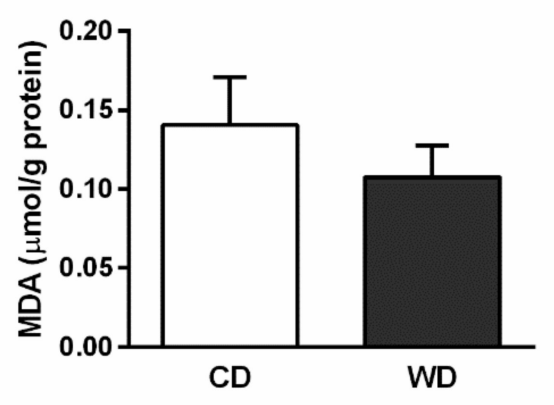

b

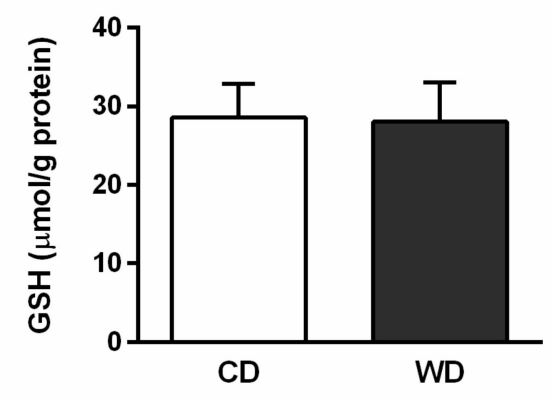

c

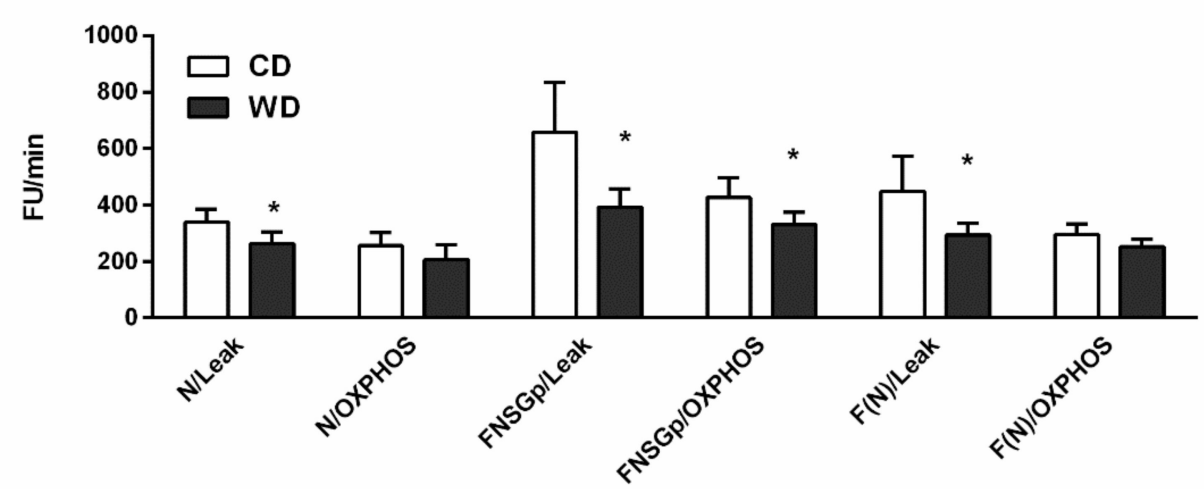

Figure 7. Markers of hepatic oxidative stress in mice fed a control diet (CD) and a Western-style diet (WD). (a) Concentration of hepatic malondialdehyde (MDA). (b) Concentration of hepatic reduced glutathione (GSH). (c) Reactive oxygen species (ROS) production in liver homogenate measured as fluorescence changes in dichlorofluorescein. LEAK, measurements in the absence of adenosine diphosphate (ADP); oxidative phosphorylation (OXPHOS), measurements in the presence of ADP (2.5 mM); N, NADH-linked substrates (pyruvate, $5 \mathrm{mM}$; glutamate, $10 \mathrm{mM}$; malate, $2 \mathrm{mM}$ ); FNSGp, fatty acid (octanoylcarnitine, $0.5 \mathrm{mM}$ ) plus NADH-linked substrates plus succinate $(10 \mathrm{mM})$ and glycerophosphate $(10 \mathrm{mM}) ; \mathrm{F}(\mathrm{N})$, octanoylcarnitine $(0.5 \mathrm{mM})$ plus malate $(2 \mathrm{mM})$. The results are expressed as the means $\pm \mathrm{SD} ;{ }^{*} p<0.05$ ( $n=6$ each group). 


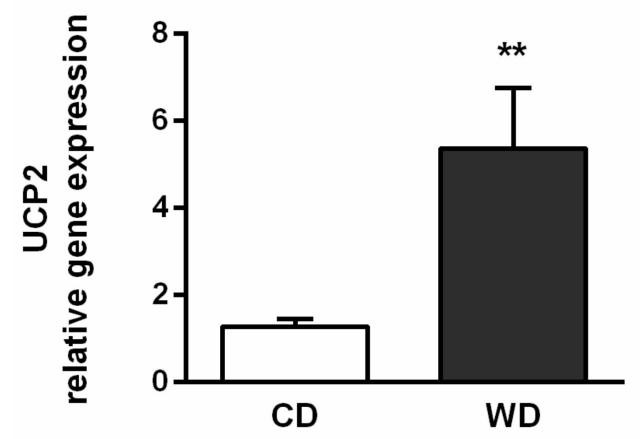

Figure 8. Uncoupling protein 2 (UCP-2) gene expression in mice fed a control diet (CD) and a Western-style diet (WD). The results are expressed as the means $\pm \mathrm{SD} ;{ }^{* *} p<0.01$ ( $n=4$ each group).

\subsection{Mitochondrial Respiration}

We observed lower oxygen consumption after the addition of succinate in both the OXPHOS and electron transfer $(\mathrm{ET})$ states $(p<0.05)$ and higher oxygen consumption induced by octanoylcarnitine in the absence of malate $(p<0.05)$, which reflects liver ketogenesis [24] (Figure 9). We also confirmed decreased enzymatic activity of SDH $(p<0.05)$ (Figure 10c). We did not find significant differences in the gene or protein expression levels of subunit A of SDH (SDHA) (Figure 10a,b).

a

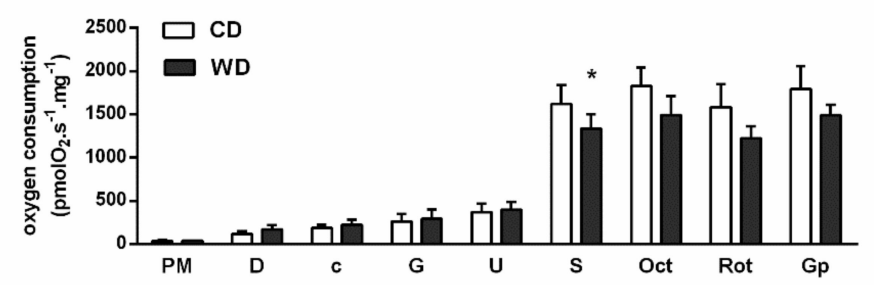

b

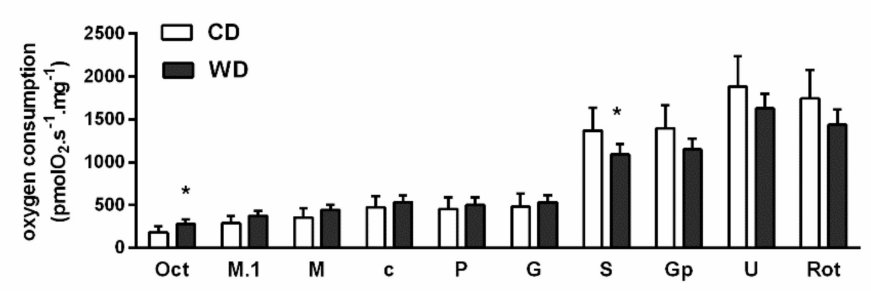

C

d
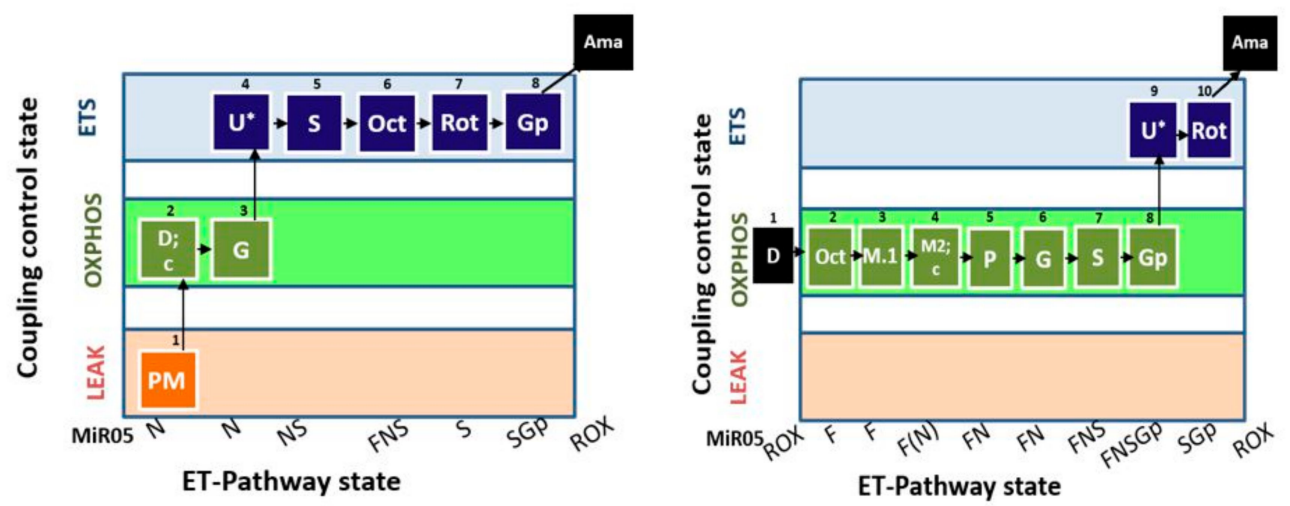

Figure 9. Mitochondrial respiration in mice fed a control diet (CD) and a Western-style diet (WD). 
(a) Respiratory protocol 1 (RP1). (b) Respiratory protocol 2 (RP2). (c) Coupling/pathway control diagram RP1. (d) Coupling/pathway control diagram RP2. Experiments were performed in $2 \mathrm{~mL}$ of mitochondrial respiratory medium MiR05. Liver homogenates were loaded at a protein concentration of $0.2 \mathrm{mg} / \mathrm{mL}$, and substrates, uncoupler, and inhibitors were gradually added according to the protocol: P (pyruvate, $5 \mathrm{mM}$ ), M (malate, $2 \mathrm{mM}$ ), M.1 (malate, $0.1 \mathrm{mM}$ ), D (ADP, $2.5 \mathrm{mM}$ ), c (cytochrome c, $10 \mu \mathrm{M}), \mathrm{G}$ (glutamate, $10 \mathrm{mM}$ ), U (carbonyl cyanide 4-(trifluoromethoxy)phenylhydrazone, 1.5-2 $\mu \mathrm{M}$ ), S (succinate, $50 \mathrm{mM}$ ), Oct (octanoylcarnitine, $0.5 \mathrm{mM}$ ), Rot (rotenone, $0.5 \mu \mathrm{M}$ ), and Gp (glycerophosphate, $10 \mathrm{mM})$. Finally, antimycin A $(2.5 \mu \mathrm{M})$ was introduced, and the data were corrected for residual oxygen consumption (ROX) as the baseline state. The results are expressed as the means $\pm \mathrm{SD}$; * $p<0.05$ ( $n=6$ each group). The LEAK state was measured in the presence of reducing substrates, but the absence of ADP, representing electron flow coupled to proton pumping to compensate for proton leaks. Oxidative phosphorylation (OXPHOS) capacity was measured in the presence of saturating concentrations of ADP (D) and defined reduced substrates. Electron transfer (ET) system (ETS) capacity was measured as oxygen consumption in the noncoupled state at optimum uncoupler (U) concentration, which was obtained by stepwise titration ${ }^{*}$ ) to induce maximum oxygen flux. The NADH ET-pathway state $(\mathrm{N})$ was obtained by the addition of NADH-linked substrates $(\mathrm{P}, \mathrm{M}, \mathrm{G})$. Succinate-induced respiratory state (S) supported the electron flux through complex II. Fatty acid (Oct) oxidation pathway control state $(\mathrm{F})$ feeds electrons through fatty acyl-CoA dehydrogenase to an electron transfer flavoprotein and further to ubiquinone. Glycerophosphate dehydrogenase complex oxidizes Gp and feeds electrons directly to ubiquinone. Residual oxygen consumption (ROX) is respiration due to oxidative side reactions that continue after inhibition of the ET-pathway (Rot, inhibitor of respiratory complex I; Ama, inhibitor of complex III) or in mitochondrial preparations incubated without the addition of fuel substrates. Outer mitochondrial membrane integrity was assessed by the addition of cytochrome c (c).
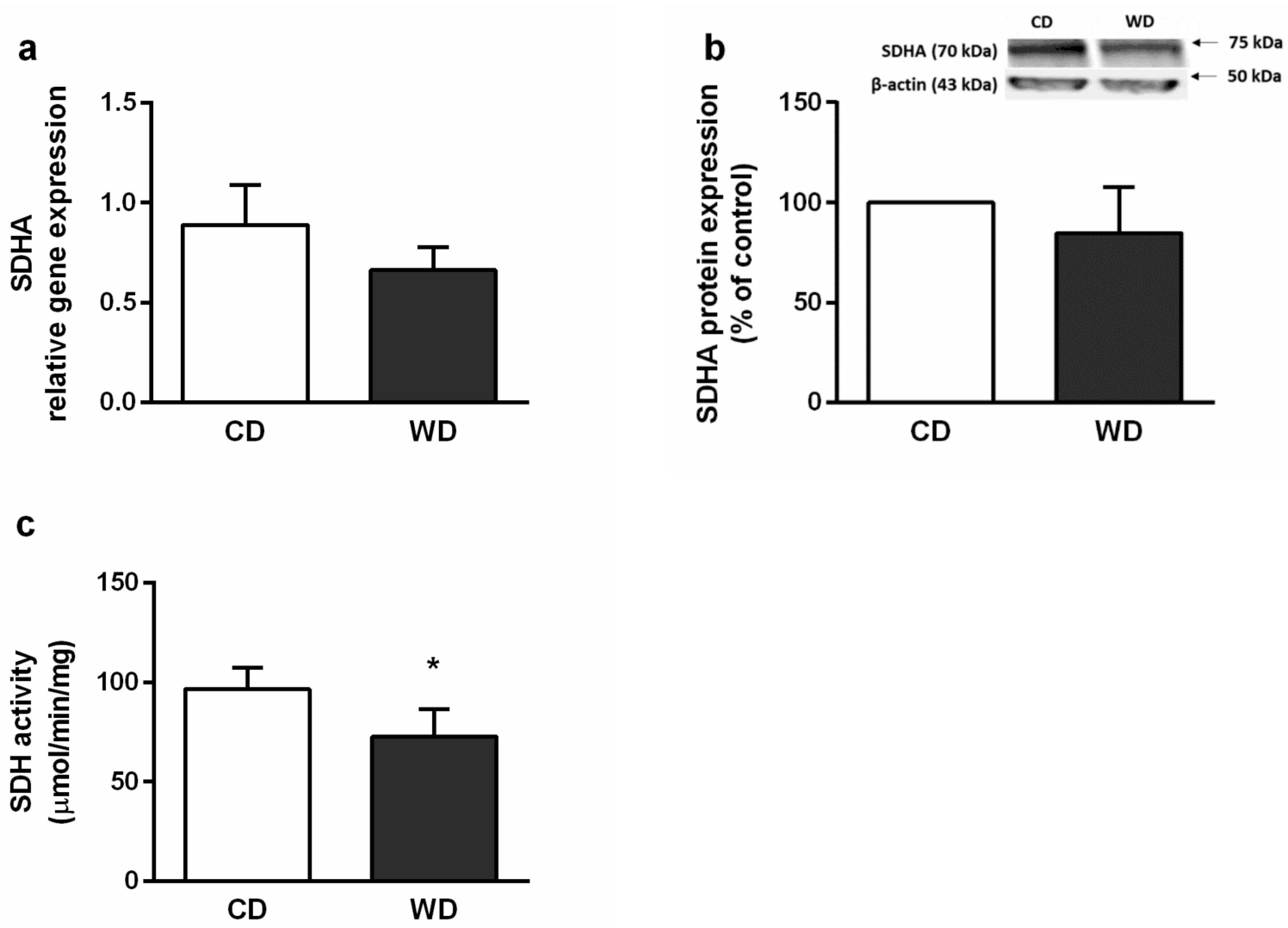

Figure 10. Hepatic succinate dehydrogenase (SDH) in mice fed a control diet (CD) and a Western-style $\operatorname{diet}(\mathrm{WD})$. (a) SDH subunit A (SDHA) relative gene expression. (b) SDH subunit A protein expression. (c) SDH enzymatic activity. The results are expressed as the means $\pm \mathrm{SD} ;{ }^{*} p<0.05$ ( $n=4-6$ each group). 


\section{Discussion}

Obesity and chronic low-grade inflammation are important risk factors for the onset of NAFLD. The weight of the animals fed the WD $(45.17 \pm 4.02 \mathrm{~g})$ was significantly higher compared with that of the controls $(30.5 \pm 3.27 \mathrm{~g})$. In male C57BL/6J mice fed a high-fat diet (HFD), a body weight of approximately $40 \mathrm{~g}$ was estimated as a critical tipping point beyond which metabolic dysfunction occurred. At this body weight, eWAT adipocytes were saturated and could not grow to store additional fat [25]. Accordingly, we found more eWAT in mice fed the WD with inflammatory cell infiltration and the presence of crown-like structures compared with the control mice, which did not exhibit marks of eWAT inflammation. The inability to safely store excess energy in the form of TGs in AT is connected to insulin resistance and metabolic inflexibility [7].

The blood analysis revealed mild hepatic injury in mice fed the WD. The liver fat content was dramatically increased in these animals, and we observed massive mixed steatosis. However, liver TGs content per se is not always predictive of NASH progression [3,26]. Increasing evidence indicates that TGs' deposition in nonadipose cells provides a mechanism by which an organism handles excess FAs and diverts them from various cytotoxic pathways [9,27,28].

Although we found elevated liver enzymes in the blood of the mice in the WD group, we did not observe hepatocellular ballooning. Liver inflammation and fibrosis in mice fed the WD were milder in comparison with the mice in the studies of Charlton et al. [18] and Krishnan et al. [21]. However, there were also differences in liver injury between the specimens in these two studies. In the former study, ballooning was present after 25 weeks of WD feeding; in the latter study, no ballooning was detected despite a prolonged feeding interval (36 weeks). A possible explanation for the discrepancy could be related to animal housing variables. In the Charlton et al. study, the mice were maintained in individual cages; in the Krishnan et al. longitudinal study, the mice were housed two mice to a cage; and in our study, the mice were housed six to a cage. Social isolation of animals has been shown to induce changes in corticosterone levels, indicating an immuno-response, and affects reactivity to a stressor [29,30]. Increasing the group size of mice was associated with decreased food intake and increased level of physical activity [31]. These differences in maintenance could partly explain the differences among these studies and highlight the importance of animal housing conditions as one of the crucial factors affecting metabolic responses.

Competition between substrates and excessive mixed nutrient entry into the ETS not matched by energy demand may overload the ETS, resulting in ROS production [32]. Oxidative stress is thought to play a significant role in NAFLD and NASH progression, although a cause-and-effect type of relationship has not yet been established [33,34]. Considering the level of GSH and malondialdehyde (MDA), we did not observe a difference in oxidative stress in the mice fed the WD in comparison with control animals. This finding is consistent with those of Charlton et al. [18] and Krishnan et al. [21], who did not find increased levels of 8-hydroxydeoxyguanosine or 4-hydroxynonenal, respectively. These results could be affected by redox alterations in C57BL/6J mice owing to a mutation in the nicotinamide nucleotide transhydrogenase enzyme [20]. However, in a human study, elevated oxidative stress was detected only in patients with histological evidence of NASH, but not in patients with simple steatosis [35]. We also measured ROS production in the liver homogenates incubated with a mixture of NADH-linked substrates, a mixture of NADH- and $\mathrm{FADH}_{2}$-linked substrates, and/or octanoylcarnitine in the presence or absence of ADP. In the absence of ADP, which mimics the state of low-energy demand, the production of ROS was significantly lower in the WD group with all the substrate mixtures examined. With the NADH- and $\mathrm{FADH}_{2}$-linked substrates, the ROS production was lower, even in the presence of ADP, in comparison with the controls. Unfortunately, we have not estimated the protein expression and the effect of UCP-2 on ROS production must be elaborated on by further studies.

We performed a detailed analysis of mitochondrial respiration. The respiration using NADH-dependent substrates was similar in both groups. In the WD group, we observed decreased succinate-activated respiration in the presence of NADH-dependent substrates in both the ET 
and OXPHOS states. We also found decreased SDH activity. This finding is in agreement with other studies. Decreased maximal ET capacity and succinate-activated ET capacity without affecting NADH-dependent respiration were observed in the livers of the obese $(\mathrm{db} / \mathrm{db})$ mice [36]. Decreased activity of liver SDH and increased plasmatic succinate concentration were found in the C57BL/6J mice fed the methionine-choline deficient diet (MCD) [37]. Succinate-driven liver respiration was also the most affected in rats fed alcohol [38]. SDH creates the only direct functional link between the tricarboxylic acid cycle (TCA) and OXPHOS, and it is optimally situated to coordinate flux through both pathways. Unlike complex I, the entry of electrons into the coenzyme Q pool from SDH is not constrained by a high proton-motive force [39-41]. SDH activity is necessary for gluconeogenesis, and succinate-driven respiration is particularly high in liver mitochondria in comparison with other tissues [39,42]. SDH predominance for driving $\mathrm{O}_{2}$ consumption is linked with the capacity to support the highest rate of ROS production in mammalian mitochondria [43]. In vivo, SDH is a relevant producer particularly in reverse electron transfer through complex I or through matrix $\mathrm{NAD}^{+}$ dehydrogenases when multiple substrates feed electrons into the coenzyme Q pool, but there is limited energy demand $[44,45]$. Under these conditions, inhibition of SDH leads to a reduction in ROS generation and decreases substrate flux through the TCA and anaplerotic/cataplerotic pathways [40]. We did not find significant differences among groups in terms of gene and protein expression of the SDHA subunit; however, we cannot exclude changes in SDH expression because we did not monitor other SDH subunits or assembly factors. The catalytic activity of SDH is also modulated by post-translational modifications and active site inhibition by TCA cycle intermediates $[41,46]$. SDH inhibition could represent an adaptive mechanism to prevent OXPHOS overflow and massive ROS production. However, inactivation of SDH leads to the accumulation of succinate, an important signaling molecule associated with inflammation, fibrosis, and carcinogenesis [41]. Obesity, type 2 diabetes, alcohol-induced liver injury, and NASH were associated with elevated levels of circulating succinate $[47,48]$. As a regulator of inflammation and fibrosis, succinate activates inflammatory and hepatic stellate cells [37].

We also found an increased ketogenic capacity in mice fed the WD, although the capacity for FA oxidation was not affected. Using octanoylcarnitine as a substrate, we neglected the regulatory role of carnitine palmitoyltransferase I. A unique feature of liver mitochondria is that hepatic TCA is not requisitely linked to $\beta$-oxidation because acetyl-CoA in excess of hepatocyte energy demand is shunted to ketogenesis [49]. While playing a minor role in the physiological fed state, ketogenesis may be a considerable factor in the state of metabolic inflexibility and in NAFLD etiology [50]. Ketogenesis could represent an ideal pathway by which to clear excess liver lipids. Levels of ketones have been reported to be increased or decreased in individuals with NAFLD [51,52]. It appears that, during the onset of obesity and hepatosteatosis, ketogenesis is activated, but later diminishes [51]. Impaired ketogenesis induced by an obesogenic diet or/and by genetic manipulation is linked to an increase in TCA flux, gluconeogenesis, oxidative stress, and severe inflammation in both mice and humans $[49,50,53]$. It was assumed that activation of ketogenesis is a potential therapeutic recourse that may increase lipid disposal [53]. However, chronic hyperketonemia decreases the peripheral oxidation of other substrates, promotes peripheral insulin resistance, and may contribute to whole-body metabolic dysfunction [54].

\section{Materials and Methods}

Animals and diets. All animals received care according to the guidelines set by the Animal-welfare Body of the Charles University (Prague, CZE). The animals were maintained under controlled conditions at $23 \pm 1{ }^{\circ} \mathrm{C}, 55 \% \pm 10 \%$ relative humidity, air exchange 12-14 times/h, 12-h light-dark cycle periods, and free access to food and water. Male C57BL/6J mice ( $26 \pm 2 \mathrm{~g}$, Velaz, Czech Republic) were randomly assigned to two groups ( $n=6$, each group) and fed ad libitum with either a standard control diet (CD, PicoLab RD 20, LabDiet) and tap water or a Western-style diet (WD, AIN-76A WD, TestDiet) and glucose $(18.1 \mathrm{~g} / \mathrm{L})$, fructose $(24 \mathrm{~g} / \mathrm{L})$ provided in water over 24 weeks. The mice were 
sacrificed under anesthesia, and blood, epididymal fat, and liver samples were harvested for further analysis; kept on ice during processing; or immediately frozen in liquid nitrogen and stored at $-80^{\circ} \mathrm{C}$.

Blood analysis. Blood analysis was performed using VetScan mammalian liver profile and a VS2 chemical analyzer (Canada).

Histology. Fresh samples of liver and epididymal fat were fixed in $4 \%$ neutral formaldehyde, embedded in paraffin, sectioned, and placed on glass slides. Hematoxylin and eosin staining was performed according to standard techniques. Liver fibrosis was quantified using Sirius red staining. The histology was evaluated by a pathologist who was blinded to the dietary condition.

Determination of TGs and cholesterol. Lipids from the livers were prepared using chloroform-methanol extraction [55]. Total cholesterol and TGs were measured using commercial kits (Roche Diagnostics $\mathrm{GmbH}$, Germany). Procedures followed the manufacturer's protocols.

Preparation of tissue homogenates and supernatants. For the measurement of mitochondrial respiration, ROS production, determination of GSH, and estimation of SDH activity, 10\% liver homogenates in cold MIR05 medium (0.5 mM EGTA, $3 \mathrm{mM} \mathrm{MgCl}, 60 \mathrm{mM}$ K-lactobionate, $20 \mathrm{mM}$ taurine, $10 \mathrm{mM} \mathrm{KH}_{2} \mathrm{PO}_{4}, 20 \mathrm{mM}$ HEPES, $110 \mathrm{mM}$ sucrose and $1 \mathrm{~g} / \mathrm{L}$ bovine serum albumin, fatty acid free, $\mathrm{pH}$ 7.1) were immediately prepared using a Potter-Elvehjem homogenizer. The homogenates were centrifuged $\left(5 \mathrm{~min}, 800 \times \mathrm{g}, 4^{\circ} \mathrm{C}\right)$, and the lipid layer was removed. Protein content was evaluated by the Bradford method [56]. For determination of liver cytokines, TBARS and Western blot analysis (WB), frozen liver samples (0.2 $\mathrm{g}$ for cytokines and TBARS and $0.1 \mathrm{~g}$ for $\mathrm{WB})$ were homogenized in $0.9 \mathrm{~mL}$ or in $1 \mathrm{~mL}$ (for WB) of precooled RIPA buffer, kept on ice for $2 \mathrm{~h}$, and centrifuged twice $(10,000 \times$ $\left.g, 4{ }^{\circ} \mathrm{C}, 10 \mathrm{~min}\right)$. The supernatants were aliquoted and either immediately used for assessment or stored at $-80^{\circ} \mathrm{C}$ until analysis. Protein content was measured by the bicinchoninic acid method [57].

Determination of liver cytokines. Concentrations of TNF- $\alpha$ and IL- 6 in the supernatant were measured by enzyme-linked immuno sorbent assay (BMS622, BMS603, Bender MedSystems, Austria) according to the manufacturer's instructions.

Western blot analysis. The proteins $(100 \mu \mathrm{g})$ were applied on Novex NuPAGE $4 \%-12 \%$ Bis-Tris gel (Invitrogen) under nonreducing conditions. The proteins were transferred to a $0.2 \mathrm{~mm}$ Hybond nitrocellulose membrane (GE Healthcare). Ponceau $S$ was the stain used, and $\beta$-actin was used as a loading control. The membranes were incubated with antibodies to $\beta$-actin (AC-74, Sigma), p21 (F-5, Santa Cruz), p53 (BP53-12, Exbio), Bcl-2 (C-2, Santa Cruz), Bax (B-9, Santa Cruz), TIMP-1 (R-18, Santa Cruz), $\alpha$-SMA (1A4, Sigma), TGF- $\beta 1$ (V, Santa Cruz), Col1A2 (COL-1, Santa Cruz), and SDHA (B-1, Santa Cruz) at $4{ }^{\circ} \mathrm{C}$ overnight. The secondary antibodies were from Santa Cruz. Detection was performed with Western blotting luminol reagent (Santa Cruz). The blots were scanned and quantified using PXi imaging system (Syngene, UK).

RNA isolation and quantitative polymerase chain reaction (qPCR). Total cellular RNA was extracted by TRIzol reagent (Invitrogen) according to the method of Chomczynski and Sacchi [58]. RNA was reverse transcribed using a cDNA reverse transcription kit and quantified with TaqMan Gene Expression Assays (Acta1 Mm00808218_g1, Fndc3a Mm01312526_m1, TGFb1 Mm03024053_m1, col1a2 Mm01165186_m1, TIMP-1 Mm01341361_m1, Bax Mm01205549_m1, Bcl2 Mm00477631_m1, Cdkn1a Mm00432448_m1, Trp53 Mm01731287_m1, SDHA Mm01352357_m1, Ucp2 Mm00627599_m1). Gene expression was analyzed using the QuantStudio 6 real-time PCR system (all obtained from Applied Biosystems, Czech Republic). The results were normalized to the 18S RNA expression.

Markers of hepatic oxidative stress. The lipoperoxidation was determined by the assessment of MDA as TBARS [59]. ROS production was monitored by using 5- (and 6-)chloromethyl-2',7'-dichlorodihydrofluorescein diacetate (CM-H2DCFDA, Invitrogen). The liver homogenate $(0.1 \mathrm{mg} / \mathrm{mL})$ was incubated in potassium medium $(100 \mathrm{mM} \mathrm{KCl}, 10 \mathrm{mM}$ Tris-HCl, $3 \mathrm{mM}$ $\mathrm{MgCl}_{2}, 4 \mathrm{mM} \mathrm{KH} \mathrm{PO}_{4}, 1 \mathrm{mM}$ EDTA, $\mathrm{pH}$ 7.4) containing $1 \mu \mathrm{M} \mathrm{CM}-\mathrm{H} 2 \mathrm{DCFDA}$ and a mixture of respiratory substrates. The substrates used and their concentrations are given in a graph legend (Figure 7). The formation of dichlorofluorescein was measured for $1 \mathrm{~h}$ in $5 \mathrm{~min}$ intervals in a Tecan Infinite M200 $\left(\lambda_{\mathrm{Ex}}=485 \mathrm{~nm}, \lambda_{\mathrm{Em}}=535 \mathrm{~nm}, 37^{\circ} \mathrm{C}\right)$. For the determination of $\mathrm{GSH}$, the liver homogenate 
was added to cold $10 \%$ metaphosphoric acid, shaken, and centrifuged $\left(20,000 \times g, 10 \mathrm{~min}, 4{ }^{\circ} \mathrm{C}\right)$. Glutathione in the supernatant was analyzed by a modified fluorimetric method [60], as described previously [61]. Mitochondrial respiration. Mitochondrial respiration was assessed by high-resolution respirometry (OROBOROS Oxygraph-2k, Austria) using the two substrate-uncoupler-inhibitor-titration (SUIT) protocols (Figure 9). Measurements were performed in MiR05 medium at $37^{\circ} \mathrm{C}$. The terminology we used for the description of respirometric results is broadly explained in a paper in preparation by the COST MitoEAGLE project consortium investigators [62].

Activity of succinate dehydrogenase. In liver homogenate, the activity of SDH was measured specrophotometrically using p-iodonitrotetrazolium as an artificial electron acceptor [63].

Statistical analysis. The data are expressed as the means \pm standard deviation (SD). All data processing was performed using GraphPad Prism 6.01 software (La Jolla, CA, USA). Group comparisons were performed using the Mann Whitney $\mathrm{U}$ test.

\section{Conclusions}

In conclusion, feeding mice the WD induced massive liver steatosis accompanied by mild inflammation and fibrosis in our experimental model. We found decreased succinate-activated mitochondrial respiration and decreased SDH activity. These findings appear to reflect a general response to chronically increased substrate flux in the mitochondria because diminished succinate-activated respiration and/or SDH activity was also found in the liver of MCD-fed mice [37], alcohol-fed rats [38], and genetically obese $\mathrm{db} / \mathrm{db}$ mice [36]. Inhibition of SDH could lead to the accumulation of succinate, an important signaling molecule associated with inflammation, fibrosis, and carcinogenesis $[39,41]$. We also found increased liver ketogenic capacity. It appears that mitochondria in this stage of the disease have adapted to the increased substrate influx. The adaptations are complex and prevent TCA and OXPHOS overflow and massive ROS production. However, the capacity of these adaptations is not limitless, and liver metabolism must be regulated with respect to peripheral tissues.

Author Contributions: Conceptualization, P.S., O.K., and Z.Č.; methodology, P.S. and O.K.; validation, O.K., Z.Č., and H.L.; formal analysis, P.S., O.K., and E.P.; investigation, P.S., O.K., E.P., T.E.M., and K.N.; resources, Z.Č.; writing-original draft preparation, P.S., O.K., and Z.Č.; writing-review and editing, P.S., O.K., Z.Č., and H.L.; supervision, Z.Č. and O.K.; project administration, Z.Č.; funding acquisition, Z.Č. All authors have read and agreed to the published version of the manuscript.

Funding: This research was funded by research program PROGRES Q40/02 and Inter-Cost LTC17044.

Acknowledgments: The authors thank Miroslav Podhola for evaluating the histological samples.

Conflicts of Interest: The authors declare no conflict of interest.

\section{Abbreviations}

$\begin{array}{ll}\alpha \text {-SMA } & \text { Alpha smooth muscle actin } \\ \text { ADP } & \text { Adenosine diphosphate } \\ \text { ALP } & \text { Alkaline phosphatase } \\ \text { ALT } & \text { Alanine transaminase } \\ \text { AT } & \text { Adipose tissue } \\ \text { BUN } & \text { Blood urea nitrogen } \\ \text { CD } & \text { Control diet } \\ \text { CoA } & \text { Coenzyme A } \\ \text { Col1A2 } & \text { Collagen type I alpha 2 chain } \\ \text { ETS } & \text { Electron transfer system }\end{array}$




$\begin{array}{ll}\text { eWAT } & \text { Epididymal white adipose tissue } \\ \text { FADH } & \text { Reduced flavin adenine dinucleotide } \\ \text { FAs } & \text { Fatty acids } \\ \text { GGT } & \gamma \text {-glutamyl transferase } \\ \text { GSH } & \text { Reduced glutathione } \\ \text { HFD } & \text { High-fat diet } \\ \text { IL-6 } & \text { Interleukin } 6 \\ \text { MCD } & \text { Methionine-choline deficient diet } \\ \text { MDA } & \text { Malondialdehyde } \\ \text { NADH } & \text { Reduced nicotinamide adenine dinucleotide } \\ \text { NAFLD } & \text { Nonalcoholic fatty liver disease } \\ \text { NASH } & \text { Nonalcoholic steatohepatitis } \\ \text { OXPHOS } & \text { Oxidative phosphorylation } \\ \text { p21 } & \text { Cyclin-dependent kinase inhibitor 1 } \\ \text { p53 } & \text { Tumor protein p53 } \\ \text { ROS } & \text { Reactive oxygen species } \\ \text { ROX } & \text { Residual oxygen consumption } \\ \text { SDH } & \text { Succinate dehydrogenase } \\ \text { SDHA } & \text { Succinate dehydrogenase subunit A } \\ \text { SUIT } & \text { Substrate-uncoupler-inhibitor-titration } \\ \text { TBARS } & \text { Thiobarbituric acid reactive substances } \\ \text { TCA } & \text { Tricarboxylic acid cycle } \\ \text { TGF- } \beta & \text { Transforming growth factor beta } \\ \text { TGs } & \text { Triglycerides } \\ \text { TIMP-1 } & \text { Tissue inhibitor of metalloproteinases-1 } \\ \text { TNF- } \alpha & \text { Tumor necrosis factor alpha } \\ \text { UCP-2 } & \text { Uncoupling protein 2 } \\ \text { WD } & \text { Western-style diet } \\ & \end{array}$

\section{References}

1. Younossi, Z.M.; Koenig, A.B.; Abdelatif, D.; Fazel, Y.; Henry, L.; Wymer, M. Global epidemiology of nonalcoholic fatty liver disease-Meta-analytic assessment of prevalence, incidence, and outcomes. Hepatology 2016, 64, 73-84. [CrossRef] [PubMed]

2. Nakagawa, H. Recent advances in mouse models of obesity- and nonalcoholic steatohepatitis-associated hepatocarcinogenesis. World J. Hepatol. 2015, 7, 2110-2118. [CrossRef] [PubMed]

3. Machado, M.V.; Michelotti, G.A.; Xie, G.; Almeida Pereira, T.; Boursier, J.; Bohnic, B.; Guy, C.D.; Diehl, A.M. Mouse models of diet-induced nonalcoholic steatohepatitis reproduce the heterogeneity of the human disease. PLoS ONE 2015, 10, e127991. [CrossRef]

4. Abenavoli, L.; Falalyeyeva, T.; Boccuto, L.; Tsyryuk, O.; Kobyliak, N. Obeticholic Acid: A New Era in the Treatment of Nonalcoholic Fatty Liver Disease. Pharmaceuticals 2018, 11, 104. [CrossRef]

5. Melzer, K. Carbohydrate and fat utilization during rest and physical activity. SPEN Eur. J. Clin. Nutr. Metab. 2011, 6, e45-e52. [CrossRef]

6. Muoio, D.M. Metabolic inflexibility: When mitochondrial indecision leads to metabolic gridlock. Cell 2014, 159, 1253-1262. [CrossRef]

7. Rutkowski, J.M.; Stern, J.H.; Scherer, P.E. The cell biology of fat expansion. J. Cell Biol. 2015, 208, 501-512. [CrossRef]

8. Mansouri, A.; Gattolliat, C.-H.; Asselah, T. Mitochondrial Dysfunction and Signaling in Chronic Liver Diseases. Gastroenterology 2018, 155, 629-647. [CrossRef]

9. Ipsen, D.H.; Lykkesfeldt, J.; Tveden-Nyborg, P. Molecular mechanisms of hepatic lipid accumulation in non-alcoholic fatty liver disease. Cell. Mol. Life Sci. 2018, 75, 3313-3327. [CrossRef] [PubMed]

10. Sunny, N.E.; Bril, F.; Cusi, K. Mitochondrial Adaptation in Nonalcoholic Fatty Liver Disease: Novel Mechanisms and Treatment Strategies. Trends Endocrinol. Metab. 2017, 28, 250-260. [CrossRef] [PubMed] 
11. Panov, A.; Orynbayeva, Z. Determination of mitochondrial metabolic phenotype through investigation of the intrinsic inhibition of succinate dehydrogenase. Anal. Biochem. 2018, 552, 30-37. [CrossRef] [PubMed]

12. Parry, S.A.; Hodson, L. Influence of dietary macronutrients on liver fat accumulation and metabolism. J. Investig. Med. 2017, 65, 1102-1115. [CrossRef] [PubMed]

13. Hodson, L.; Rosqvist, F.; Parry, S.A. The influence of dietary fatty acids on liver fat content and metabolism. Proc. Nutr. Soc. 2019, 79, 30-41. [CrossRef] [PubMed]

14. Luukkonen, P.K.; Sadevirta, S.; Zhou, Y.; Kayser, B.; Ali, A.; Ahonen, L.; Lallukka, S.; Pelloux, V.; Gaggini, M.; Jian, C.; et al. Saturated Fat Is More Metabolically Harmful for the Human Liver Than Unsaturated Fat or Simple Sugars. Diabetes Care 2018, 41, 1732-1739. [CrossRef] [PubMed]

15. Legeza, B.; Marcolongo, P.; Gamberucci, A.; Varga, V.; Banhegyi, G.; Benedetti, A.; Odermatt, A. Fructose, Glucocorticoids and Adipose Tissue: Implications for the Metabolic Syndrome. Nutrients 2017, $9,426$. [CrossRef] [PubMed]

16. Ibrahim, S.H.; Hirsova, P.; Malhi, H.; Gores, G.J. Animal Models of Nonalcoholic Steatohepatitis: Eat, Delete, and Inflame. Dig. Dis. Sci. 2016, 61, 1325-1336. [CrossRef]

17. Luo, Y.; Burrington, C.M.; Graff, E.C.; Zhang, J.; Judd, R.L.; Suksaranjit, P.; Kaewpoowat, Q.; Davenport, S.K.; O'Neill, A.M.; Greene, M.W. Metabolic phenotype and adipose and liver features in a high-fat Western diet-induced mouse model of obesity-linked NAFLD. Am. J. Physiol. Endocrinol. Metab. 2016, 310, E418-E439. [CrossRef]

18. Charlton, M.; Krishnan, A.; Viker, K.; Sanderson, S.; Cazanave, S.; McConico, A.; Masuoko, H.; Gores, G. Fast food diet mouse: Novel small animal model of NASH with ballooning, progressive fibrosis, and high physiological fidelity to the human condition. Am. J. Physiol. Gastrointest. Liver Physiol. 2011, 301, G825-G834. [CrossRef]

19. Stephenson, K.; Kennedy, L.; Hargrove, L.; Demieville, J.; Thomson, J.; Alpini, G.; Francis, H. Updates on Dietary Models of Nonalcoholic Fatty Liver Disease: Current Studies and Insights. J. Liver Res. 2018, 18, 5-17. [CrossRef]

20. Ronchi, J.A.; Figueira, T.R.; Ravagnani, F.G.; Oliveira, H.C.; Vercesi, A.E.; Castilho, R.F. A spontaneous mutation in the nicotinamide nucleotide transhydrogenase gene of C57BL/6J mice results in mitochondrial redox abnormalities. Free Radic. Biol. Med. 2013, 63, 446-456. [CrossRef]

21. Krishnan, A.; Abdullah, T.S.; Mounajjed, T.; Hartono, S.; McConico, A.; White, T.; LeBrasseur, N.; Lanza, I.; Nair, S.; Gores, G.; et al. A longitudinal study of whole body, tissue, and cellular physiology in a mouse model of fibrosing NASH with high fidelity to the human condition. Am. J. Physiol. Gastrointest. Liver Physiol. 2017, 312, G666-G680. [CrossRef] [PubMed]

22. SUIT Reference Protocol. Available online: https://wiki.oroboros.at/index.php/SUIT_reference_protocol (accessed on 27 October 2019).

23. Kleiner, D.E.; Makhlouf, H.R. Histology of Nonalcoholic Fatty Liver Disease and Nonalcoholic Steatohepatitis in Adults and Children. Clin. Liver Dis. 2016, 20, 293-312. [CrossRef] [PubMed]

24. DiMarco, J.P.; Hoppel, C. Hepatic mitochondrial function in ketogenic states. Diabetes, starvation, and after growth hormone administration. J. Clin. Investig. 1975, 55, 1237-1244. [CrossRef] [PubMed]

25. Van Beek, L.; van Klinken, J.B.; Pronk, A.C.; van Dam, A.D.; Dirven, E.; Rensen, P.C.; Koning, F.; Willems van Dijk, K.; van Harmelen, V. The limited storage capacity of gonadal adipose tissue directs the development of metabolic disorders in male C57Bl/6J mice. Diabetologia 2015, 58, 1601-1609. [CrossRef] [PubMed]

26. Sunny, N.E.; Satapati, S.; Fu, X.; He, T.; Mehdibeigi, R.; Spring-Robinson, C.; Duarte, J.; Potthoff, M.J.; Browning, J.D.; Burgess, S.C. Progressive adaptation of hepatic ketogenesis in mice fed a high-fat diet. Am. J. Physiol. Endocrinol. Metab. 2010, 298, E1226-E1235. [CrossRef] [PubMed]

27. Prentki, M.; Madiraju, S.R. Glycerolipid metabolism and signaling in health and disease. Endocr. Rev. 2008, 29, 647-676. [CrossRef]

28. Ponziani, F.R.; Pecere, S.; Gasbarrini, A.; Ojetti, V. Physiology and pathophysiology of liver lipid metabolism. Expert Rev. Gastroenterol. Hepatol. 2015, 9, 1055-1067. [CrossRef]

29. Kalliokoski, O.; Teilmann, A.C.; Jacobsen, K.R.; Abelson, K.S.; Hau, J. The lonely mouse-Single housing affects serotonergic signaling integrity measured by 8-OH-DPAT-induced hypothermia in male mice. PLoS ONE 2014, 9, e111065. [CrossRef]

30. Kappel, S.; Hawkins, P.; Mendl, M.T. To Group or Not to Group? Good Practice for Housing Male Laboratory Mice. Animals 2017, 7, 88. [CrossRef] 
31. Bailoo, J.D.; Murphy, E.; Varholick, J.A.; Novak, J.; Palme, R.; Wurbel, H. Evaluation of the effects of space allowance on measures of animal welfare in laboratory mice. Sci. Rep. 2018, 8, 713. [CrossRef]

32. Nolan, C.J.; Prentki, M. Insulin resistance and insulin hypersecretion in the metabolic syndrome and type 2 diabetes: Time for a conceptual framework shift. Diabetes Vasc. Dis. Res. 2019, 16, 118-127. [CrossRef] [PubMed]

33. Garcia-Ruiz, C.; Fernandez-Checa, J.C. Mitochondrial Oxidative Stress and Antioxidants Balance in Fatty Liver Disease. Hepatol. Commun. 2018, 2, 1425-1439. [CrossRef] [PubMed]

34. Sumida, Y.; Niki, E.; Naito, Y.; Yoshikawa, T. Involvement of free radicals and oxidative stress in NAFLD/NASH. Free Radic. Res. 2013, 47, 869-880. [CrossRef]

35. Koliaki, C.; Szendroedi, J.; Kaul, K.; Jelenik, T.; Nowotny, P.; Jankowiak, F.; Herder, C.; Carstensen, M.; Krausch, M.; Knoefel, W.T.; et al. Adaptation of hepatic mitochondrial function in humans with non-alcoholic fatty liver is lost in steatohepatitis. Cell Metab. 2015, 21, 739-746. [CrossRef] [PubMed]

36. Holmstrom, M.H.; Iglesias-Gutierrez, E.; Zierath, J.R.; Garcia-Roves, P.M. Tissue-specific control of mitochondrial respiration in obesity-related insulin resistance and diabetes. Am. J. Physiol. Endocrinol. Metab. 2012, 302, E731-E739. [CrossRef]

37. Li, Y.H.; Woo, S.H.; Choi, D.H.; Cho, E.H. Succinate causes alpha-SMA production through GPR91 activation in hepatic stellate cells. Biochem. Biophys. Res. Commun. 2015, 463, 853-858. [CrossRef]

38. Han, D.; Johnson, H.S.; Rao, M.P.; Martin, G.; Sancheti, H.; Silkwood, K.H.; Decker, C.W.; Nguyen, K.T.; Casian, J.G.; Cadenas, E.; et al. Mitochondrial remodeling in the liver following chronic alcohol feeding to rats. Free Radic. Biol. Med. 2017, 102, 100-110. [CrossRef]

39. Tretter, L.; Patocs, A.; Chinopoulos, C. Succinate, an intermediate in metabolism, signal transduction, ROS, hypoxia, and tumorigenesis. Biochim. Biophys. Acta (BBA)-Bioenerg. 2016, 1857, 1086-1101. [CrossRef]

40. Drose, S. Differential effects of complex II on mitochondrial ROS production and their relation to cardioprotective pre- and postconditioning. Biochim. Biophys. Acta (BBA)-Bioenerg. 2013, 1827, 578-587. [CrossRef]

41. Bezawork-Geleta, A.; Rohlena, J.; Dong, L.; Pacak, K.; Neuzil, J. Mitochondrial Complex II: At the Crossroads. Trends Biochem. Sci. 2017, 42, 312-325. [CrossRef]

42. Kappler, L.; Hoene, M.; Hu, C.; von Toerne, C.; Li, J.; Bleher, D.; Hoffmann, C.; Bohm, A.; Kollipara, L.; Zischka, H.; et al. Linking bioenergetic function of mitochondria to tissue-specific molecular fingerprints. Am. J. Physiol. Endocrinol. Metab. 2019, 317, E374-E387. [CrossRef] [PubMed]

43. Ralph, S.J.; Moreno-Sanchez, R.; Neuzil, J.; Rodriguez-Enriquez, S. Inhibitors of succinate: Quinone reductase/Complex II regulate production of mitochondrial reactive oxygen species and protect normal cells from ischemic damage but induce specific cancer cell death. Pharm. Res. 2011, 28, 2695-2730. [CrossRef] [PubMed]

44. Quinlan, C.L.; Orr, A.L.; Perevoshchikova, I.V.; Treberg, J.R.; Ackrell, B.A.; Brand, M.D. Mitochondrial complex II can generate reactive oxygen species at high rates in both the forward and reverse reactions. J. Biol. Chem. 2012, 287, 27255-27264. [CrossRef] [PubMed]

45. Robb, E.L.; Hall, A.R.; Prime, T.A.; Eaton, S.; Szibor, M.; Viscomi, C.; James, A.M.; Murphy, M.P. Control of mitochondrial superoxide production by reverse electron transport at complex I. J. Biol. Chem. 2018, 293, 9869-9879. [CrossRef] [PubMed]

46. Meyer, J.G.; Softic, S.; Basisty, N.; Rardin, M.J.; Verdin, E.; Gibson, B.W.; Ilkayeva, O.; Newgard, C.B.; Kahn, C.R.; Schilling, B. Temporal dynamics of liver mitochondrial protein acetylation and succinylation and metabolites due to high fat diet and/or excess glucose or fructose. PLoS ONE 2018, 13, e0208973. [CrossRef]

47. Serena, C.; Ceperuelo-Mallafre, V.; Keiran, N.; Queipo-Ortuno, M.I.; Bernal, R.; Gomez-Huelgas, R.; Urpi-Sarda, M.; Sabater, M.; Perez-Brocal, V.; Andres-Lacueva, C.; et al. Elevated circulating levels of succinate in human obesity are linked to specific gut microbiota. ISME J. 2018, 12, 1642-1657. [CrossRef]

48. Schofield, Z.; Reed, M.A.; Newsome, P.N.; Adams, D.H.; Gunther, U.L.; Lalor, P.F. Changes in human hepatic metabolism in steatosis and cirrhosis. World J. Gastroenterol. 2017, 23, 2685-2695. [CrossRef]

49. Satapati, S.; Sunny, N.E.; Kucejova, B.; Fu, X.; He, T.T.; Mendez-Lucas, A.; Shelton, J.M.; Perales, J.C.; Browning, J.D.; Burgess, S.C. Elevated TCA cycle function in the pathology of diet-induced hepatic insulin resistance and fatty liver. J. Lipid Res. 2012, 53, 1080-1092. [CrossRef] 
50. Cotter, D.G.; Ercal, B.; Huang, X.; Leid, J.M.; D'Avignon, D.A.; Graham, M.J.; Dietzen, D.J.; Brunt, E.M.; Patti, G.J.; Crawford, P.A. Ketogenesis prevents diet-induced fatty liver injury and hyperglycemia. J. Clin. Investig. 2014, 124, 5175-5190. [CrossRef]

51. Mannisto, V.T.; Simonen, M.; Hyysalo, J.; Soininen, P.; Kangas, A.J.; Kaminska, D.; Matte, A.K.; Venesmaa, S.; Kakela, P.; Karja, V.; et al. Ketone body production is differentially altered in steatosis and non-alcoholic steatohepatitis in obese humans. Liver Int. 2015, 35, 1853-1861. [CrossRef]

52. Vice, E.; Privette, J.D.; Hickner, R.C.; Barakat, H.A. Ketone body metabolism in lean and obese women. Metabolism 2005, 54, 1542-1545. [CrossRef] [PubMed]

53. Fletcher, J.A.; Deja, S.; Satapati, S.; Fu, X.; Burgess, S.C.; Browning, J.D. Impaired ketogenesis and increased acetyl-CoA oxidation promote hyperglycemia in human fatty liver. JCI Insight 2019. [CrossRef] [PubMed]

54. Abdurrachim, D.; Woo, C.C.; Teo, X.Q.; Chan, W.X.; Radda, G.K.; Lee, P.T.H. A new hyperpolarized 13C ketone body probe reveals an increase in acetoacetate utilization in the diabetic rat heart. Sci. Rep. 2019, 9, 1-13. [CrossRef] [PubMed]

55. Bligh, E.G.; Dyer, W.J. A rapid method of total lipid extraction and purification. Can. J. Biochem. Physiol. 1959, 37, 911-917. [CrossRef] [PubMed]

56. Bradford, M.M. A rapid and sensitive method for the quantitation of microgram quantities of protein utilizing the principle of protein-dye binding. Anal. Biochem. 1976, 72, 248-254. [CrossRef]

57. Smith, P.K.; Krohn, R.I.; Hermanson, G.T.; Mallia, A.K.; Gartner, F.H.; Provenzano, M.D.; Fujimoto, E.K.; Goeke, N.M.; Olson, B.J.; Klenk, D.C. Measurement of protein using bicinchoninic acid. Anal. Biochem. 1985, 150, 76-85. [CrossRef]

58. Chomczynski, P.; Sacchi, N. Single-step method of RNA isolation by acid guanidinium thiocyanate-phenol-chloroform extraction. Anal. Biochem. 1987, 162, 156-159. [CrossRef]

59. Ohkawa, H.; Ohishi, N.; Yagi, K. Assay for lipid peroxides in animal tissues by thiobarbituric acid reaction. Anal. Biochem. 1979, 95, 351-358. [CrossRef]

60. Kand'ar, R.; Zakova, P.; Lotkova, H.; Kucera, O.; Cervinkova, Z. Determination of reduced and oxidized glutathione in biological samples using liquid chromatography with fluorimetric detection. J. Pharm. Biomed. Anal. 2007, 43, 1382-1387. [CrossRef]

61. Kucera, O.; Rousar, T.; Stankova, P.; Hanackova, L.; Lotkova, H.; Podhola, M.; Cervinkova, Z. Susceptibility of rat non-alcoholic fatty liver to the acute toxic effect of acetaminophen. J. Gastroenterol. Hepatol. 2012, 27, 323-330. [CrossRef]

62. Gnaiger, E.; Aasander Frostner, E.; Abdul Karim, N.; Abdel-Rahman, E.A.; Abumrad, N.A.; Acuna-Castroviejo, D.; Adiele, R.C.; Amati, F. Mitochondrial respiratory states and rates. MitoFit Prepr. Arch. 2019. [CrossRef]

63. Hartwig, S.; Kotzka, J.; Lehr, S. Isolation and quality control of functional mitochondria. Methods Mol. Biol. 2015, 1264, 9-23. [PubMed]

(C) 2020 by the authors. Licensee MDPI, Basel, Switzerland. This article is an open access article distributed under the terms and conditions of the Creative Commons Attribution (CC BY) license (http://creativecommons.org/licenses/by/4.0/). 